\title{
Sustainability Index of Mining: A Case Study in Two Companies
}

\author{
Aline Aparecida Silva Pereira ${ }^{1}$, Eduardo Gomes $\operatorname{Salgado}^{2}$, Ronaldo Luiz Mincato ${ }^{1}$, Augusto Duarte Alvarenga ${ }^{1}$ \& \\ Luis Antônio Coimbra Borges ${ }^{3}$ \\ ${ }^{1}$ Department of Natural Sciences, Federal University of Alfenas, Alfenas, Brasil \\ ${ }^{2}$ Department of Exact Sciences, Federal University of Alfenas, Alfenas, Brasil \\ ${ }^{3}$ Department of Forest Engineering, Federal University of Lavras, Lavras, Brazil \\ Correspondence: Aline Aparecida Silva Pereira, Department of Natural Sciences, Federal University of Alfenas, \\ Rua Gabriel Monteiro da Silva, n 700, Centro, Alfenas, Brasil. E-mail: alyneaspereira@hotmail.com
}

Received: August 20, 2019

Accepted: September 25, 2019 Online Published: November 23, 2019

doi:10.5539/jms.v9n2p115

URL: https://doi.org/10.5539/jms.v9n2p115

\begin{abstract}
Since the inclusion of mineral exploration as an activity with sustainable potential in Agenda 21, the development of metrics to evaluate and monitor the sector has been deemed necessary. Thus, to obtain accurate information and to develop an evaluation index, a set of indicators based on the Triple Bottom Line was selected. The methodology based on Gravity, Urgency and Trend (GUT Matrix), developed in 1981 by Kepner and Tregoe, was used to evaluate the weights assigned to the indicators. The results were organized according to the level of relevance of the environmental, social and economic criteria at levels 4, 3 and 2, respectively. A ranking was created among the indicators of each criterion that gave rise to the proposed evaluation index. Through a qualitative analysis, it was possible to validate the proposed index as to its efficiency, applicability, ability to reverse the current situation of the sector and monitoring of the exploration activity, proposing improvements \& enabling the minimization of negative impacts. Finally, understand that it is possible to accept mining as a sustainable activity.
\end{abstract}

Keywords: GUT, multi-criteria analysis, stakeholders, sustainability

\section{Introduction}

Minerals are prominent in the history of humankind, and so much improvement in the quality of life in recent years is practically unimaginable without its exploration. However, with population growth and the post-industrial revolution period, the demand for mineral resources has grown exponentially. With the increase of mineral exploration and production standards arises the need for a targeted management that has as main purpose the tangibility of sustainable practices, so that the negative impacts are minimized (Mason et al., 2011; Nunes, 2006).

Immersed in a market characterized by a variable and multiple stakeholder group, with mostly conflicting objectives, the industrial sector has a capacity for evolution and adaptation to the slow and unstable sustainable system. It is known that the adoption of sustainable practices that are environmentally responsible, socially correct and economically viable has the power to collaborate so that negative impacts are minimized throughout the life cycle of the exploration. However, environmental and social issues, even if governed by international laws and decrees, have less impact on the management decision-making process (Carter, 2012; Driussi\& Jansz, 2006).

Delai and Takahashi (2011) state that the measurement and assessment of sustainability within organizations is recognized as an engine capable of driving the inclusion of sustainability as an important issue throughout the life cycle of the activity in the decision-making process and also in the organizational system. The use of methodologies that analyse multiple criteria and that are able to evaluate criteria quantitatively and qualitatively are considered the best alternatives for the correct valuation of the Triple Bottom Line.

Due to the large amplitude of the mineral sector and the multiple objectives and stakeholders, the use of Multi-criteria Decision Making Methods (MCDM) as auxiliary tools for a concise assessment is considered a step forward in this research model. These tools help to select, classify and prioritize the criteria under analysis by assigning weights to them, regardless of the conflicts between the parties and objectives (Oskarson, 2015). 
The GUT (Gravity, Urgency and Trend) method, capable of evaluating multiple criteria in an integrated way and providing extremely reliable results, was used for this work.

Gravity represents the possible damage or loss that can occur in a given situation. It should be analysed by considering the intensity or negative impact that the problem can cause if it is not solved. Urgency represents the question of the existing time for a problem or situation to be resolved, taking into account the available time. Trend represents the potential for growth of the problem and the probability of becoming even greater over time (Vasconcelos et al., 2013).

From the application of this model to the ranking of the 65 selected indicators, it was possible to diagnose which criterion has the greatest weight within the base that make up the Triple Bottom Line and to elaborate an index of sustainability evaluation for the mineral sector. The purpose of this index is to diagnose the degree of sustainability of companies that carry out mineral exploration and the main mistakes made by the managers, thus allowing the elaboration of an action plan aimed at minimizing and mitigating negative impacts. The main peculiarity will be the possibility of continuous monitoring for each company during the accomplishment of the exploration project and the classification or not of these companies as sustainable. After completing the development stage, two case studies were carried out with the objective of evaluating the applicability of the index and making it compatible with the needs of the mineral sector as a whole.

\section{Material and Methods}

\subsection{Quantitative Analysis}

Stakeholders based on their own experiences, knowledge and problem perception usually assign the criterion weights (Yilmas \& Harmancioglu, 2010). Representatives of the mining sector, of the public power, NGO (representing the interests of internal and external society involved in mineral exploration activities), and the academy (students and teachers) were selected as stakeholders for this work.

After the selection of the stakeholders, the criteria matrix (based on the Triple Bottom Line) and alternatives (selected from the systematic review of the literature) were developed. Through the matrix, a closed questionnaire was prepared and sent to 25 (twenty-five) representatives, from which, based on their extensive knowledge of the subjects covered, weighs in relation to each of the alternatives or sub-criteria.

The weight given to each criterion is relative to the approach of the GUT method and generates a final ranking as to the degree of importance of each indicator and its inference in the degree of sustainability. To obtain a final value of the hierarchy, the calculation will be performed using:GxUxT = the final weight reached by the criterion. After the attribution of the weights, it is estimated that the higher the result the higher the priority (Vasconcelos et al., 2013). The score to be assigned follows the guidelines described in Table 1.

Table 1. Values of the weights to be assigned to the criteria

\begin{tabular}{|c|c|c|c|}
\hline Score & Gravity & Urgency & Trend \\
\hline 5 & Extremely serious & Immediate action required. & If nothing is done, the potential for aggravation is immediate. \\
\hline 4 & Very serious & Very urgent. & It will get worse in a short time. \\
\hline 3 & Serious & $\begin{array}{l}\text { Urgent.Deserves attention in the short term. } \\
\text { Solve as soon as possible. }\end{array}$ & It will get worse. \\
\hline 2 & Not too serious & Little urgent. Can wait for some time. & It tends to get worse. \\
\hline 1 & Not serious & Can wait. No hurry. & $\begin{array}{l}\text { It will keep on tending to not get worse, and there may even be } \\
\text { an improvement. }\end{array}$ \\
\hline
\end{tabular}

Source. Adapted from Klassman, 2011.

After finding the total weight of each criterion based on the judgment made by the stakeholders, the obtained data were normalized using equation 1 in order to allocate the values in the same range of values, avoiding that one dimension overlap in relation to the others:

Source: Donget al., 2014.

$$
r_{i j}=\frac{f_{i j}}{\sqrt{\sum_{j=1}^{n} f_{i j}^{2}}}
$$

Where: $r_{i j}=$ total value of the criteria; $i=$ alternative; $j=$ criterion; $f_{i j}=$ matrix composed of the number of alternatives multiplied by the number of criteria.

From there, the final sum $\left(\mathrm{W}_{\mathrm{f}}\right)$ of the weights of each of the criteria was calculated and a final ranking was 
elaborated. Equation 2 will be used for the sum of the total weights:

$$
\mathrm{w}_{\mathrm{f}}=\sum \alpha_{\mathrm{wt}}+\sum \beta_{\mathrm{wt}}+\sum \gamma_{\mathrm{wt}} \cdots
$$

Where: $\mathrm{W}_{\mathrm{f}}=$ final sum of the weights assigned by all stakeholders; $\Sigma \alpha_{\mathrm{wt}}$ indicator $1 ; \beta_{\mathrm{wt}}$ indicator $2 ; \gamma_{\mathrm{wt}}=$ indicator 3 .

\subsection{Qualitative Analysis}

As key questions for the validation of this metric, the purpose is to answer the following questions: Is the proposed index compatible with the reality of companies in developing countries? Does the proposal apply to both large and small companies, and are the conditions in which they are accessible? Does the index comply with relevant environmental legislation? From the results obtained, it is hoped that it will be possible to generalize theoretical propositions, since this is the objective of the case study research, to expand and generalize theories (Yin, 2009).

After selecting the research area and the companies, a structured questionnaire,considered transdisciplinary and integrative, was developed to be applied in the selected companies. The weights defined by the stakeholders, applied to the questions related to the indicator approached, will be used for the final sum of the percentage acquired by the companies regarding the degree of sustainability.

Equation 3 will be used for the sum from the answers obtained through the application of the questionnaire.

$$
=\frac{(p e s o A 1)+\operatorname{peso}(A 2)+\operatorname{peso}(A 3) \ldots \text { peso }(S 1)+\operatorname{peso}(S 2)+\operatorname{peso}(S 3) \ldots p e s o(E 1)+p e s o(E 2)+p e s o(E 3) \ldots}{n}
$$

Where: $\sum$ sf means the sum of the final sustainability; A1, A2, and so on refer to environmental indicators; S1, $\mathrm{S} 2$ and the others refer to social indicators; E1, E2 and so on refer to the economic criteria. When these attributes are present, they are assigned the value 1 , and when they are absent the value 0 ; weight refers to the value attributed by the GUT methodology (Table 1); $\mathrm{n}$ refers to the number of criteria that make up the index. It should be noted that some of the weights would be assigned negative values because they are undesirable indicators within the mineral sustainability, i.e., when they occur, they are considerednegative influences of the activity. These indicators are:irreversible impacts, generation of toxic effluents, release of greenhouse gases (GHG), tailings dam vulnerability, silting of bodies of water, toxic dust, presence of erosion, complete change of landscape, environmental accidents (historical), deforested area, environmental pending matters, current environmental proceedings, public civil action, signing of conduct adjustment term (CAT); visual impact, explosive detonation, health (history of pollution-related diseases and labour fines).

Based on the explanation of the concepts of weak and strong sustainability and the interception curve of the graph elaborated in the work of Motta (1995), that represents the ecological optimum of degradation, it is accepted that the companies that reach a percentage equal to or above $70 \%$ of the weights will be considered sustainable, as discussed in the theoretical framework.For this purpose, the sum of the weights obtained by the environmental, social and economic criteria will be calculated and divided by 3 (number of criteria), addressing the percentage of each individual criterion and in an integrated way. Companies that do not reach this percentage will be described as necessary to a reframing of their activities, through the desirable sustainable standard.

\subsection{Area of Study}

The micro region of Poços de Caldas, one of the ten micro regions that make up the southern and southeastern mesoregion of Minas Gerais, was selected as the study area. This region is highly known for its mining potential and for the various mining ventures in the region. A quantitative survey of the current projects in the region was carried out through the Regional Superintendency of Environmental Protection (SUPRAM/Varginha) and later two companies were selected, one small and one large sized.

These companies were selected based on their size in order to obtain information on the socio-environmental and economic objectives and perspectives of a small and large company, and to develop their activities in a region with high mining potential. In addition, the coverage area of these companies is close to priority conservation areas. 


\section{Results and Discussions}

The return of the questionnaires sent to interested parties was $64 \%$. The results of the applied questionnaires express that the environmental criteria as level 4, followed by the social criteria as level 3 and finally the economic criteria as level 2 are the elements of greater gravity and interference in the issue of sustainability in mining.

The sub criteria related to the environmental criterion were defined as level 4 , with a percentage of $44 \%$ (Figure 1). This assessment shows the insecurity of stakeholders as to the various impacts that have been caused by the activity throughout history on the environment and society, which have a negative impact on the economy through the implementation of recovery measures and compensation for damages. According to the experts, this criterion was the most important among those analysed.

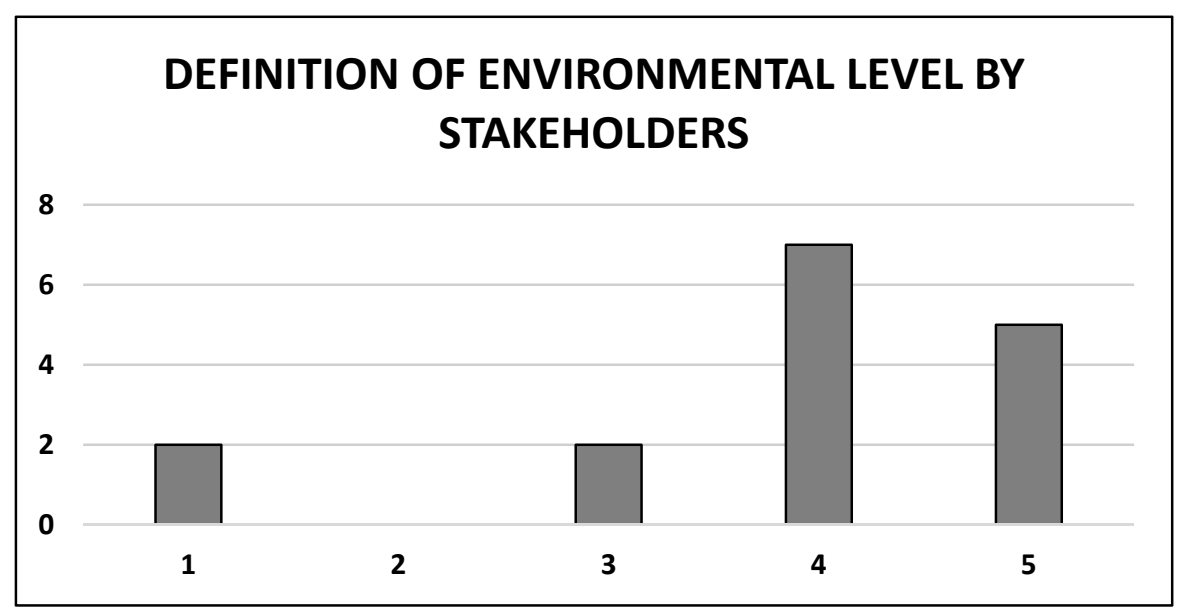

Figure 1. Attribution of weights to environmental indicators by stakeholders with a percentage equal to $44 \%$, classifying it as level 4

Regarding the ranking of indicators related to the environmental criteria, the ten priorities were defined as: Solid waste management plan $(81.9 \%)$, presence of water resources in the extraction area $(80.9 \%)$, effluent treatment (80.9\%),presence of ecological corridor (79.04\%), development and implementation of the Recovery Plan for Degraded Areas (RPDA) (78.09\%), generation of toxic effluents (77.14\%), irreversible impacts (77.14\%), release of greenhouse gases $(76.19 \%)$, vulnerability of the tailings dam $(76.19 \%)$ and siltation of rivers and lakes (74.28\%).

Approved in 2010, Law No. 12,305, which instituted the National Solid Waste Policy, is considered an important instrument for Brazil's progress in addressing the main environmental, social and economic problems arising from the incorrect management of the waste generated (MMA, 2010). Regarding mining, the solid waste management plan, defined as the main sub-criterion of the environmental criterion, is a legal document that proves the company's ability to manage the waste produced throughout the exploration processes, promoting the reduction of waste generation, proposing sustainable consumption practices and the environmentally correct disposal of the tailings generated.

Water, considered by stakeholders as the second sub-criterion of greater weight within the environmental criteria, is a resource that requires an intense search for innovations that promote its better management and control of the generation of potentially toxic effluents, reducing the risks of negative impacts such as increased eutrophication, sedimentation, contamination by heavy metals, among others.Relating water to mining, a table of overlapping concentrations of areas of mineral exploration with areas of high water demand can be presented, as well as the Brazilian Southeast, which has a great urban network.

According to Ciminelli (2010), in addition to conflicts originated in order to maintain the good quality of the water resources present in the mining area, there is an increasing need of mining companies in expanding spatial scales for the use of ores, in order to obtain greater use and reduction of costs and investments, starting to be considered no more a local intervention, but a territorial one.

The mandatory submission of PRAD is based on the principle that areas that are environmentally disturbed by mining activities must be returned to the community or landowner under conditions that are desirable and 
appropriate to the return of the original land use or to those necessary for the implementation of another future use (Lima et al., 2006).However, according to Sánchez (2010), there are few comprehensive studies about the results of the recovery plans and he questions the situation of the PRADs, if they are actually implemented, if they present a list of effective measures for environmental recovery, if companies have human and financial resources for the correct implementation of the measures envisaged.

Another question is whether companies are able to present clear evidence to demonstrate the results obtained in the recovery of degraded areas. The principle guiding the restoration of degraded ecosystems, especially by mining, is to restore soil functions in order to provide adequate initial conditions for revegetation. The main and most difficult restoration to be done in degraded soil is qualitative and refers to its potential for vegetation development, including retention of water and nutrients (Duarte \& Casagrande, 2006).

The sharp destruction of natural habitats is considered as one of the main causes of the extinction of animal and plant species. The fragmentation of continuous areas that become isolated mosaics of the initial habitat causes effects like the border effect and the isolation of habitats and consequently diminish the ecological relations, genetic variability, loss of exotic species, among others (Pimm \& Raven, 2000; Saunder et al., 2001). In addition, vegetation is an important agent of physical impediment to the action of weathering agents, preventing damages such as discharging and carrying of particles caused by the droplets, reducing runoff and increasing the time of water absorption by the soil (Bezerra, 2013; Gomes \& Silva, 2013).

The closure of mines and the future use of extraction areas require a profound reflection on the legacy and environmental liabilities caused by mining. Therefore, at the 1992 Rio Summit, several authors emphasized the importance of exploration, technological innovation and environmental rehabilitation. The post-extraction phase, within the life cycle of a mine is considered one of the most important in the evaluation of environmental sustainability, since it is when the balance of benefits and harms caused are examined (Younger, 2006; Sanchez, 2011; Amezaga et al., 2011).

Regarding the sub criteria approach related to social criteria, the attribution of weights by stakeholders reflects the importance and magnitude of the possible impacts of each criterion, being defined as level 3 (Figure 2), with a percentage of $56 \%$. Thus, the damages are considered as regular, needing resolution as soon as possible and tend to worsen in the medium term.

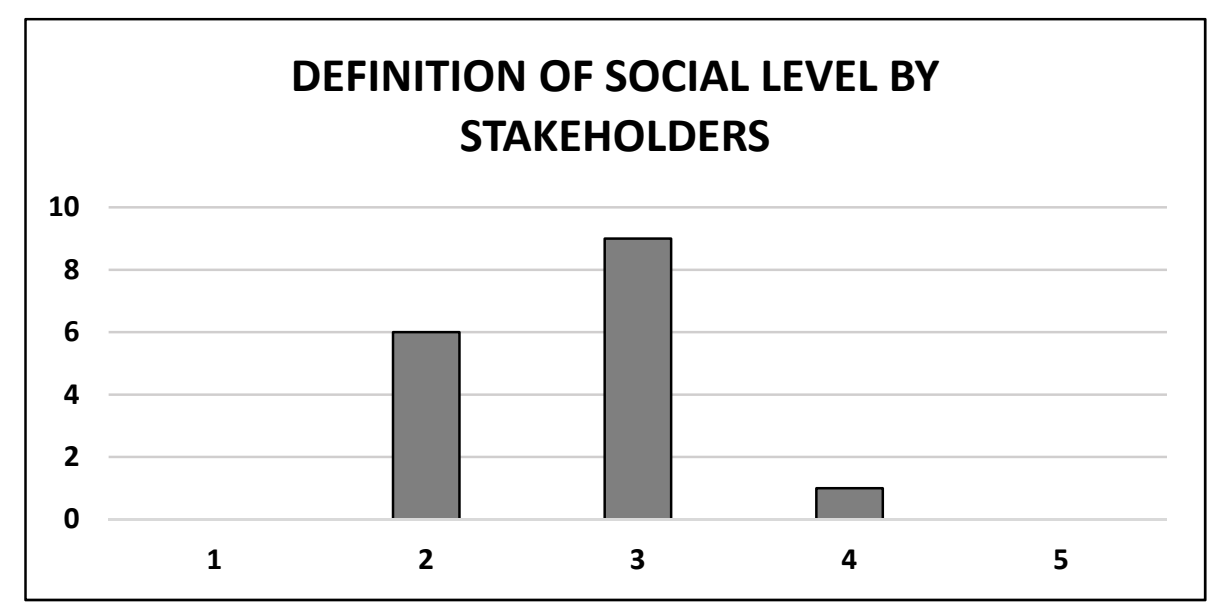

Figure 2. Attribution of weights to social indicators by stakeholders with a percentage equal to $56 \%$, classifying it as level 3

Regarding the ranking of the sub criteria related to the social criterion, the ten priorities were defined as: Safe working conditions (67.61\%), Sound impact (63.08\%), Training plan for servers (62.85\%), Visual impact (62.85\%), Female participation (positions held) (61.90\%), Detonation of explosives (60.95\%), Health (history of diseases related to pollution) and safety $(60.95 \%)$, Generation of direct and indirect jobs $(60 \%)$, Illiteracy rate $(57.14 \%)$ and Social certification $(57.14 \%)$.

The ISO 26000 Standard of November 1, 2010, known as the first international standard dealing with corporate social responsibility, raises hopes that companies can better cope with the environment around them. The standard is based on the principles of accountability, ethical behaviour, stakeholder consideration, legislation and 
human rights. However, according to Ibase, in Brazil, there is no legal obligation for companies to publish the social report, which makes it difficult to analysecritically the real situation so far. Many companies do so for reasons ranging from ethical commitment to the competitive advantages that this can provide, encouraging companies to disclose the social and environmental actions developed, annually.

The forms of distribution of mineral resources are an important consideration for mineral sustainability, where there are intense debatesat international level on the aspects of the distribution of the values collected by mineral processing. Many believe that local communities, where the negative impacts are most pronounced, should receive a greater proportion of benefits (ICMM, 2012; Moran \& Kunz, 2014).

Investments related to the development and management of environmental resources have a complexity of variables to consider. The economies of many developing countries, and especially mining towns, depend heavily on resources from local exploration (Davies \& Osano, 2005). However, as discussed in the work of Yu et al. (2005), in one of the major mining cities in eastern China, most of the mineral resource reserves tend to be depleted and the return of resources hardly satisfies the development and growth of the extraction areas.

Interpretive systems and management tools can help strengthen interconnections between operations, the environment and the community, facilitating record keeping, understanding and relationship between parties, and meeting the expectations and goals of all stakeholders. Thus, it is possible to evaluate the stages of the processes that make up the exploration project, promoting improvements between the stages of the past, present and future (Gomez \& Hebert, 2015; Moran \& Kunz, 2014).

When questioned about the economic criteria and its indicators, the stakeholders defined that the criterion economy has the lowest level among the principles adopted by the Triple Bottom Line. When the relative percentage among stakeholders was admitted, the economic criterion was described as level 2 (Figure 3) with a percentage of $44 \%$ in relation to the distribution of weights. Thus, characterizing the criterion denominated as responsible for minor damages within the mineral sustainability, in which the priority is low and can wait for the solution of the problems because it can only get worse in the long term.

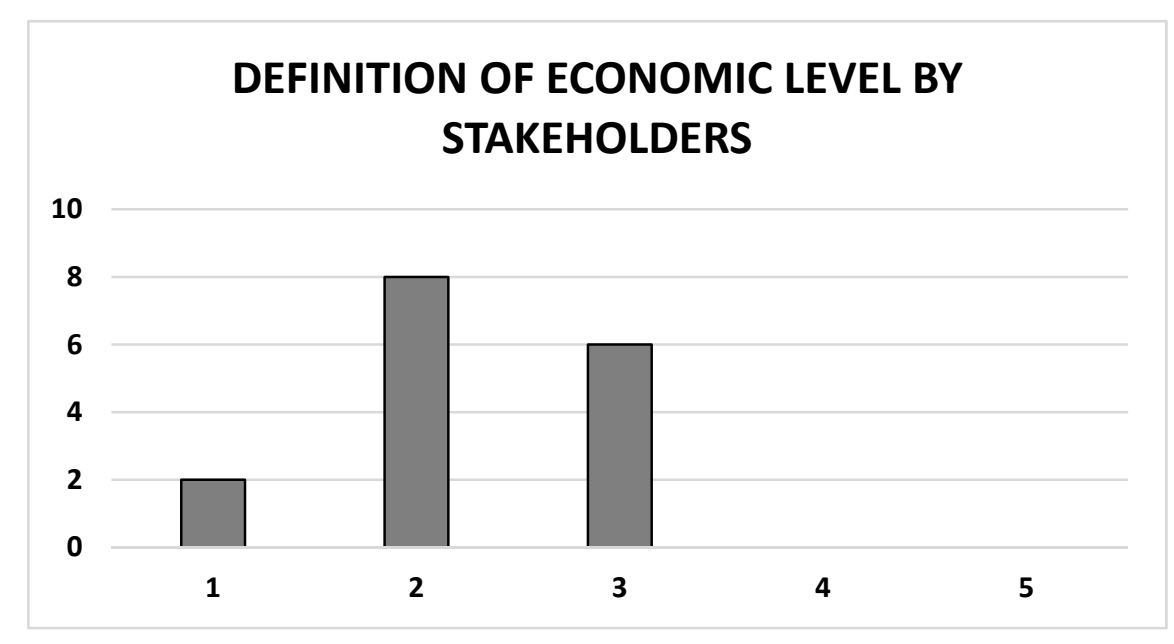

Figure 3. Attribution of weights to the indicators that make up the economic criterion, by stakeholders, classifying it as level 2 with $44 \%$

The ranking order of the ten sub criteria that compose the economic criterion in the ranking addressed by this research are: Investment in environmental technology (55.23\%), Local investment (roads, highways, basic sanitation) (54.28\%), Annual production (51.42\%), Financial compensation (CEFEM) (51.42\%), Number of employees (50.4\%), Regional economic development (49.52\%), Gross revenue (49.52\%), Regional economic development (48.57\%), Local suppliers (41.90\%), Municipal net available income (purchasing power of each citizen) $(41.90 \%)$.

Mineral resources were considered responsible for the economic growth of many countries. However, most of these countries were unable to achieve distributed growth, focused on equity among stakeholders, which can be explained by poor economic management and little applicability in investments and returns to the community. Mining, like any other industrial sector, must be delineated so that the products provide a positive outcome both 
for companies, aiming the expected profit, and for human and ecosystem well-being (ICMM, 2012; Kumah, 2006).

Many developed and developing countries, endowed with mineral resources, have for centuries been able to maintain mineral extraction as a source of wealth and activity, but today they are in retrograde situation (Kumah, 2006), reducing the economy and seeking new sources of exploration and development. This fact can be explained by the adoption of unsustainable and tenuous practices, which trigger the exhaustion of these resources and the non-promotion of an equitable development among the parties involved.

Shanxi Province, in China, is a model of mineral exploration on unsustainable bases, where the wide range of coal resources arranged in different parts of the province promote the current development of the local economy. However, the survival of the population is threatened by deficit of environmental goods and services with unsatisfactory quality of life and in the process of exhaustion. Besides the depletion of resources that energize the local economy are in the process of exhaustion, the economy is stagnant and reduced due to the low return on local investment (Hong et al., 2011).

However, it is important to note that one of the most important aspects related to the elaboration of the proposed sustainability index and the attribution of the weights addressed throughout this discussion come from the aim of minimizing problems related to the scarcity of mineral resources and the minimization and mitigation of risks and negative impacts. Thus, it makes sustainability tangible for the mining sector and allows it to be assessed, understood and improved at each assessment with the adoption of the selected criteria.

\subsection{Index of Evaluation of Mineral Sustainability}

As described by Sich et al. (2007) for an index to meet the expected needs, in addition to having a concise and efficient basis, it must also contain numerical information to be used for the representation and interpretation of its application. By the application of logics and quantification of the established criteria, it is possible to perform a final calculation. Since it is an activity that has qualitative and quantitative indicators, the valuation of the criteria for the elaboration of this index was based on the GUT method, transforming all the data into quantitative ones, making them useful and with real values (Table 2). 
Table 2. Weights assigned to the indicators for the final sum of the index (TO BE CONTINUED)

\begin{tabular}{|c|c|c|c|c|c|}
\hline ENVIRONMENTAL & WEIGHT & SOCIAL & WEIGHT & ECONOMIC & WEIGHT \\
\hline $\begin{array}{l}\text { Solid Waste Management } \\
\text { Plan }\end{array}$ & 0.041910331 & Safe working conditions & 0.061631944 & $\begin{array}{l}\text { Investment in } \\
\text { environmental technology }\end{array}$ & 0.085798817 \\
\hline $\begin{array}{l}\text { Presence of water resources } \\
\text { in the extraction area }\end{array}$ & 0.041423002 & Sound impact & 0.058159722 & $\begin{array}{l}\text { Local investment (roads, } \\
\text { highways, basic sanitation) }\end{array}$ & 0.084319527 \\
\hline Treatment of effluents & 0.041423002 & $\begin{array}{l}\text { Training plan for } \\
\text { servers }\end{array}$ & 0.057291667 & Annual production & 0.079881657 \\
\hline $\begin{array}{l}\text { Presence of ecological } \\
\text { corridor }\end{array}$ & 0.040448343 & Visual impact & 0.057291667 & Financial compensation & 0.079881657 \\
\hline $\begin{array}{l}\text { Recovery Plan for Degraded } \\
\text { Areas (RPDA) }\end{array}$ & 0.039961014 & $\begin{array}{l}\text { Female participation } \\
\text { (positions held) }\end{array}$ & 0.056423611 & Number of employees & 0.078402367 \\
\hline Irreversible impacts & 0.039473684 & $\begin{array}{l}\text { Detonation of } \\
\text { explosives }\end{array}$ & 0.055555556 & $\begin{array}{l}\text { Regional economic } \\
\text { development }\end{array}$ & 0.076923077 \\
\hline Generation of toxic effluents & 0.039473684 & $\begin{array}{l}\text { Health (history of } \\
\text { diseases related to } \\
\text { pollution) }\end{array}$ & 0.055555556 & Gross revenue & 0.076923077 \\
\hline Release of greenhouse gases & 0.038986355 & $\begin{array}{l}\text { Generation of direct and } \\
\text { indirect jobs }\end{array}$ & 0.0546875 & $\begin{array}{l}\text { Regional economic } \\
\text { development }\end{array}$ & 0.075443787 \\
\hline $\begin{array}{l}\text { Vulnerability of the tailings } \\
\text { dam }\end{array}$ & 0.038986355 & Illiteracy rate & 0.052083333 & Local suppliers & 0.065088757 \\
\hline Silting of rivers, lakes, etc. & 0.038011696 & Social certification & 0.052083333 & $\begin{array}{l}\text { Municipal net available } \\
\text { income (purchasing power } \\
\text { of each citizen) }\end{array}$ & 0.065088757 \\
\hline Toxic dust & 0.038011696 & $\begin{array}{l}\text { Presence of cultural } \\
\text { heritage }\end{array}$ & 0.052083333 & $\begin{array}{l}\text { Equity rate (minimum rate } \\
\text { of return required by } \\
\text { investors to carry out a } \\
\text { given investment) }\end{array}$ & 0.063609467 \\
\hline Presence of erosion & 0.037524366 & Cultural initiative & 0.051215278 & $\begin{array}{l}\text { Community Development } \\
\text { Fund ( } 1 \% \text { of net income) }\end{array}$ & 0.063609467 \\
\hline Mine Closure Plan & 0.037037037 & Labour fines & 0.051215278 & $\begin{array}{l}\text { Social development fund } \\
\text { (1\% gross revenue net } \\
\text { revenue) }\end{array}$ & 0.060650888 \\
\hline $\begin{array}{l}\text { Complete change of } \\
\text { landscape }\end{array}$ & 0.037037037 & Childcare assistance & 0.050347222 & Municipal GDP & 0.044378698 \\
\hline $\begin{array}{l}\text { Environmental Impact } \\
\text { Assessment }\end{array}$ & 0.036549708 & Municipal HDI & 0.048611111 & & \\
\hline $\begin{array}{l}\text { Measures to prevent } \\
\text { environmental damage }\end{array}$ & 0.036549708 & $\begin{array}{l}\text { Analysis of the } \\
\text { schooling index of } \\
\text { employees }\end{array}$ & 0.048611111 & & \\
\hline Future use of extraction areas & 0.03460039 & $\begin{array}{l}\text { Certification of } \\
\text { operational risks }\end{array}$ & 0.048611111 & & \\
\hline $\begin{array}{l}\text { Environmental accidents } \\
\text { (history) }\end{array}$ & 0.03411306 & $\begin{array}{l}\text { Relationship with the } \\
\text { community (history of } \\
\text { demonstrations, public } \\
\text { acceptance of the } \\
\text { activity, request for } \\
\text { public intervention). }\end{array}$ & 0.044270833 & & \\
\hline Deforested area & 0.033625731 & & & & \\
\hline $\begin{array}{l}\text { Environmental pending } \\
\text { matters }\end{array}$ & 0.033138402 & & & & \\
\hline $\begin{array}{l}\text { PPA (percentage of area } \\
\text { occupied by facilities within } \\
\text { PPAs) }\end{array}$ & 0.032651072 & & & & \\
\hline $\begin{array}{l}\text { Legal reserve (presence or } \\
\text { absence) }\end{array}$ & 0.031676413 & & & & \\
\hline $\begin{array}{l}\text { Current environmental } \\
\text { proceedings } \\
\text { Public civil action }\end{array}$ & 0.030701754 & & & & \\
\hline & 0.030214425 & & & & \\
\hline EIA - RIMA & 0.030214425 & & & & \\
\hline $\begin{array}{l}\text { Signing of Conduct } \\
\text { Adjustment Term (CATs) }\end{array}$ & 0.029239766 & & & & \\
\hline $\begin{array}{l}\text { Periodic environmental } \\
\text { assessment }\end{array}$ & 0.028752437 & & & & \\
\hline \multirow[t]{2}{*}{ Environmental certification } & 0.028265107 & & & & \\
\hline & 1 & & 1 & & 1 \\
\hline
\end{tabular}


The quest for sustainability is characterized by long-term vision, monitoring of results and incorporation of stakeholders in the results obtained. Thus, the indicators become a measure that indicates the real situation and the future to which they are submitted, making possible the adaptation of the company's behaviour, correction and mitigation of negative impacts. The measure of each indicator and its interrelationship can be used to illustrate, in a simple and objective way, the current situation of sustainability for the mineral sector and its consequences (Ezequiel, 2010; Guicarães \& Feichas, 2009; Therivel, 2010).

An important aspect of sustainability, which determines the success of its evaluation as an integrated system, is that there is no remote possibility of determining the degree of sustainability of an activity considering only the indicators of one of the system-wide criteria. Since sustainability is determined by a set of factors that are complementary, all must be included in the final calculation of the index (Bouni, 1996). For this purpose, equation 3 has been developed, integrating all the indicators and thus, it will be possible to determine the degree of sustainability in which the companies of the mineral sector meet.

\subsection{Application of the Proposed Evaluation Metric}

For the application and validation of the proposed index, two projects were selected, one small and one large sized. The selection of these companies occurred because they are located in a municipality marked by the intense presence of the Atlantic Forest and Cerrado domains described as Brazilian hotspots, several fragmented areas and permanent preservation areas, which generates a strong interest in the conservation and proposition of recovery measures for degraded areas.

Through the application of a structured questionnaire, it was possible to investigate the degree of sustainability of the selected companies and still classify them as sustainable or not. Individual weights, defined by the stakeholders (Table 1), were assigned to each of the indicators, when present, and the final sum was achieved by applying equation 3. For the environmental criterion, the small company obtained $72.27 \%$ of the weights, whereas the large company obtained $67.78 \%$ of the weights. Regarding the social criterion, $47.22 \%$ of the weights and $73.17 \%$; and, for the economic criterion, $82.95 \%$ and $86.81 \%$, respectively (Figure 4).

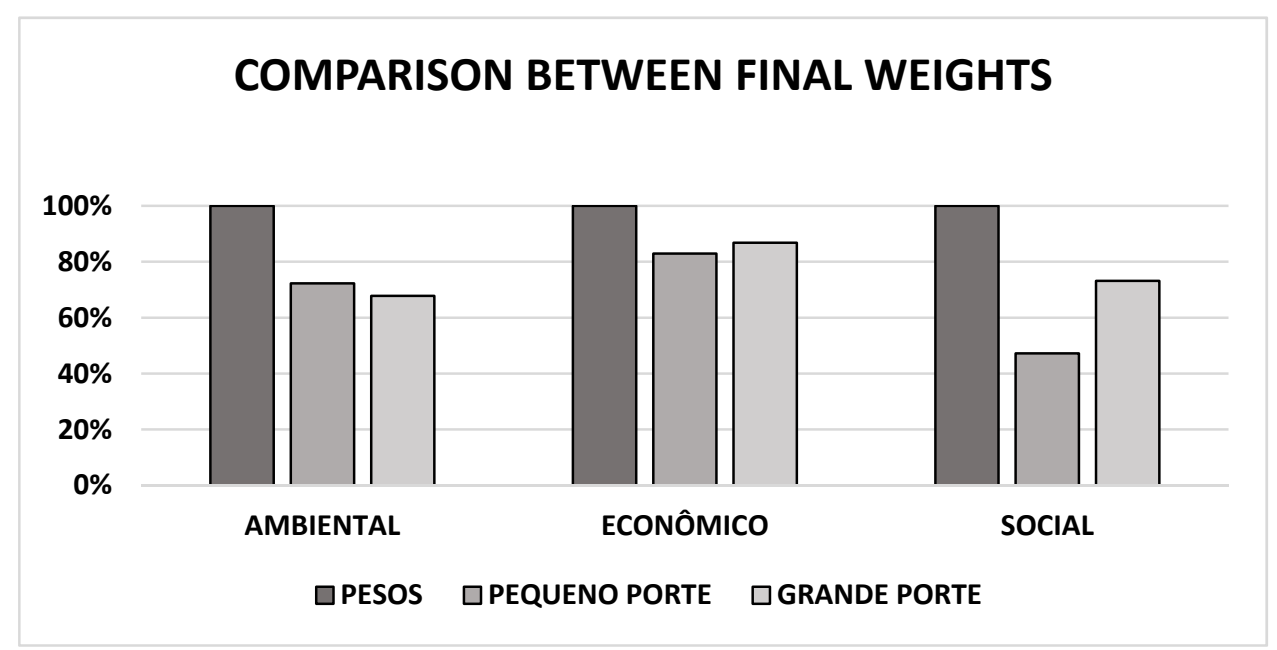

Figure 4. Results and comparison between weights stipulated by stakeholders and achieved by the small and large companies

Some authors, among them (Lourenço \& Carvalho, 2013), state that when the subject is sustainability, the spotlight has been on the environmental dimension in particular. However, when this criterion is observed in isolation it is possible to observe innumerable difficulties and challenges faced by the evaluated companies, where only one of them can achieve sustainability in this dimension. It is important to emphasize that considering the fact of investment capacity, it would be expected that the large company obtained a good score in this criterion, since its economic return is more stable and this is one of the major excuses for the non-adherence of clean measures and technologies. However, as noted, large companies often still do not consider this criterion of total relevance.

Studies carried out by Sarkis et al. (2010) have shown a significant comparison between economic, environmental and social aspects, indicating that sustainability, while social, needs a detailed research and an 
involvement of the criterion as essential and of total importance, as demonstrated in the results obtained here (Lourenço \& Carvalho, 2013). Indicators referring to the social criterion demonstrate, even in the factors considered critical, to be in worse performance and once again, keeping the expectations of other decades, the indicators with better performance are those that make up the economic criterion. (Garcia \& Garcia, 2014; Lourenço \& Carvalho, 2013).

Thus, from an integrated analysis of the results obtained by the selected criteria none of the companies can be considered sustainable. The great differential and generator of prominence in the industrial environment is due today to the ethical stance and commitment of the companies with their shareholders, with the community where it operates and with the environment. When present, the connection between corporate metrics and sustainability demonstrates governance practices that emit transparency, fairness and accountability to all parties (Bollmann \& Marques, 2001).

Therefore, in the conclusion of the case studies, it is believed that the proposed index meets the needs described as essential by Andrade et al. (2013), which is adapted to the reality of companies from both developing and developed countries, and can be applied in small, medium and large companies as proposed by Sciliar (2007); Filho and Viana (2012). It also covers the interests of the various parties and allows their equitable development as proposed by Agenda 21, generating the minimum possible environmental impacts and stipulating mitigation measures for those that are still inevitable, promoting a satisfactory quality of life for present and future generations.

\section{Conclusions}

It is possible to accept mining as a sustainable activity. It is believed that the economic growth and development expected by investors and owners of mineral exploration companies are optimized with the adoption of exploration methods that reduce impacts. With adequate return to local communities, the benefits will also be multiple. From the use of infrastructure left as legacy to the municipality until the qualification and professionalization of society, allowing the performance and development of the municipality to remain after the closure of activities, contributing in general to the quality of life of present and future generations.

With the accomplishment of the multiple case studies, as a form of validation of the sustainability index of the proposed mineral activity and from the exactness of the results obtained, it is considered of great importance, efficiency and applicability. The innovation of this model in relation to the others consists in the aggregation of both qualitative and quantitative indicators, where with the Multiple Criteria Decision Making (MCDM) it was possible to value each indicator and assign them weights by specialists in the cause, representing all interested parties.

In each of the stages, it was possible to observe the inclusion of comprehensive, specific and critical indicators, as well as to address the topics defined as essential by the legislation for the mining activity in separate and integrated perspectives. Thus, allowing an effective evaluation of each indicator and criterion and their interference in the whole, allowing for improvements, minimization and mitigation of impacts. However, it is proposed that new works be carried out with as many stakeholders as possible and in different regions, thus verifying the different perspectives encountered and closing a universal set of criteria through the various interests.

\section{Acknowledgment}

This research was supported by CAPES Foundation linked to the Ministry of Education of Brazil.

\section{References}

Amezaga, J. S., Rotting, T. S., \& Younger, P. L. (2011). A Rich Vein? Mining and the Pursuit of Sustainability. Environmental Science \& Technology, 45, 21-26. https://doi.org/10.1021/es101430e

Andrade, R. M. (2012). Qualidade de vida no trabalho dos colaboradores da empresa Farben S/A indústria química. Monografia, 52 f (Pós-graduação em gestão empresarial), Universidade do Extremo Sul Catarinense, Criciúma.

Bezerra, J. F. R. (2013). Reabilitação de áreas degradadas por erosão em São Luis/MA. In A. J. T. Guerra \& C. O. Jorge M do (Eds.), Processos erosivos e recuperação de áreas degradadas (pp. 31-65). São Paulo: Oficina de Textos.

Bolmann, H. A., \& Marques, D. M. (2001). Gestão ambiental integrada de bacias hidrográficas: bacia do rio Cachoeiras - São Mateus do Sul-PR. Revista Brasileira de Recursos Hídricos, 6(3), 45-65. https://doi.org/10.21168/rbrh.v6n3.p45-65

Bouni, C. (1996). Indicateurs de développement durable: l'enjeu d'organiser une information hétérogène pour 
préparer une decision multicritère. In Colloque International, Abbay De Fontevraud-Indicateurs De Développemente Durable (p. 14). Livro de Trabalhos. Paris: Application des Sciences de l'Action (AScA).

BRASIL. Lei No 12.305 de 02 de agosto de 2010. Institui a Política Nacional de Resíduos Sólidos; altera a Lei $\mathrm{N}^{\circ} 9605$, de 12 de fevereiro de 1998; e dá outras providências.

Carter, B. (2012). Boom, Bust, Boom: A Story about Copper, the Metal that Runs the World (1st ed.). Scribner, New York.

Ciminelli, V. S. T. (2010). Os Recursos Hídricos e a Indústria Mineral - uma plataforma para o desenvolvimento nacional sustentável (p. 4). Nota técnica à Academia Bras. Ciências. Rio de Janeiro.

Davies, T. C., \& Osano, O. (2005). Sustainable mineral development: case study from Kenya. Geological Society London Special Publications, 250(1), 87-94. https://doi.org/10.1144/GSL.SP.2005.250.01.09

Delai, I., \& Takahashi, S. (2011). Sustainability measurement system: A reference model proposal. Social Responsibility Journal, 7(3), 438-471. https://doi.org/10.1108/17471111111154563

Dong, J., Chi, Z. D., Fu, C., Huang, Q., \& Ni, M. (2014). Energy environment economy assessment oswast management systems from a life cicle perspective: model development and case study. Applied Energy, 114, 400-408. https://doi.org/10.1016/j.apenergy.2013.09.037

Driussi, C., \& Jansz, J. (2006). Pollution minimisation practices in the Australian mining and mineral processing industries. Journal of Cleaner Production, 14, 673-681. https://doi.org/10.1016/j.jclepro.2004.09.004

Duarte, R. M. R., \& Casagrande, J. C. (2006). A interação solo-vegetação na recuperação de áreas degradadas. In L.M. Barbosa (Ed.), Manual para recuperação de áreas degradadas do estado de São Paulo: matas ciliares do interior paulista (pp. 2-69). São Paulo: Instituto de Botânica.

Ezequiel, A. S. R. (2010). Utilização de indicadores em Avaliação Ambiental Estratégica. 143 f. Dissertação (Mestrado em Engenharia do Ambiente, perfil Ordenamento do Território e Impactes Ambientais). Universidade Nova de Lisboa, Lisboa.

Garcia, D. S. S., \& Garcia, H. S. (2014). Dimensão social do princípio da sustentabilidade: Uma análise do mínimo existencial ecológico. In SOUZA, Maria Claudia da Silva Antunes de; GARCIA, Heloise Siqueira. (orgs.), Lineamentos sobre sustentabilidade segundo Gabriel Real Ferrer. Dados eletrônicos. Itajaí: UNIVALI.

Giannetti, B. F., \& Almeida, C. M. B. V. (2006). Ecologia Industrial: Conceitos, ferramentas e aplicações. São Paulo, Editora Edgard Blücher.

Gomes, L. F. A. M., Camanho, R., Camanho, T. M., Macedo, M. G. C., \& Martins, L. G. B. (2013). Promoting sustainability in mining: multicriteria assignment of resources in Vale. International Conference on Multiple Criteria Decision Making, Malaga, Spain.

Gomez, J. C., \& Herbert, J. H. (2015). Environmental analysis of mining operations: Dynamic tools for impact Assessment. Minerals Engineering, 76, 87-96. https://doi.org/10.1016/j.mineng.2014.10.024

Guimarães, R. P., \& Feichas, S. A. Q. (2009). Desafios na Construção de Indicadores de Sustentabilidade. Ambiente e Sociedade, Campinas, XII(2). https://doi.org/10.1590/S1414-753X2009000200007

Hong, G., Kai, Z., \& Hanwen, Z. (2011). Research on sustainable development of resource-based small industrial and mining cities-A case study of Yangquanqu town, Xiaoyi, Shanxi Province, China. Procedia Engineering, 21, 633-640. https://doi.org/10.1016/j.proeng.2011.11.2059

ICMM. (2012). Our Work: Sustainable Development Framework. International Council on Mining and Metals. London. Retrieved from http://www.icmm.com/our-work/ sustainable-development-framework

ÍNDICE DE DESENVOLVIMENTO SUSTENTÁVEL (ISE). (2016). Retrieved from http://isebvmf.com.br/arquivos/494/ISE_2016___GLOSSARIO.pdf

Kepner, C. H., \& Tregoe, B. B. (1981). O administrador nacional (p. 58). São Paulo: Atlas.

Klassmann, A. B., Brehm, F. A., \& Moraes, C. A. (2011). Percepção dos funcionários dos riscos e perigos nas operações realizadas no setor de fundição. R. Est. Tecnológicos, 7(2), 142-162.

Kumah, A. (2006). Sustainability and gold mining in the developing world. Journal of Cleaner Production, 14, 315-323. https://doi.org/10.1016/j.jclepro.2004.08.007

Lima, H. M., Flores, J. C. C., \& Costa, F. L. (2006). Plano de recuperação de áreas degradadas versus plano de 
fechamento de mina: um estudo comparativo. REM: Revista Escola de Minas, Ouro Preto, 59(4), 397-402. https://doi.org/10.1590/S0370-44672006000400008

Lourenço, M. L., \& Carvalho, D. (2013). Sustentabilidade social e desenvolvimento sustentável. Revista de Administração, Contabilidade e Economia RACE, Unoesc, 12(1), 9-38.

Mason, L., Prior, T., Mudd, G., \& Giurco, D. (2011). Availability, addiction and alternatives: three criteria for assessing the impact of peak minerals on society. Journal of Cleaner Production, 19(9-10), 958-966. https://doi.org/10.1016/j.jclepro.2010.12.006

MINISTÉRIO DO MEIO AMBIENTE. (2010). Retrieved from http://www.mma.gov.br/pol\%C3\%ADtica-de-res\%C3\%ADduos-s\%C3\%B3lidos

Moran, C. J., \& Kunz, N. C. (2014). Sustainability as it pertains to minerals and energy supply and demand: a new interpretative perspective for assessing progress. Journal of Cleaner Production, 84, 16-26. https://doi.org/10.1016/j.jclepro.2012.09.038

Motta, R. A. (1995). Contabilidade ambiental: teoria, metodologia e estudos de casos no Brasil. IPEA, Rio de Janeiro.

Norma Internacional. (2010). ISO 26000-Diretrizes sobre Responsabilidade Social, No Brasil, no dia 8 de dezembro de 2010.

Nunes, P. H. F. (2006). Mineração e meio ambiente: o desenvolvimento sustentável (p. 241). Curitiba: Jurua.

Oskarson, P. (2015). Governing India's bauxite mineral expansion: Caught between facility ating investment and mediating social concerns. The Extractive Industries and Society, 3. https://doi.org/10.1016/j.exis.2015.05.007

Pimm, S. L., \& Raven, P. (2000). Extinction by numbers. Nature, 403, 843-845. https://doi.org/10.1038/35002708

Rodrigues, F. S., \& Viana, M. B. (2011). Gestão da água: o desafio do zinco em Vazante/MG. In: Recursos Minerais e Sustentabilidade Territorial: grandes minas. In F. R. C. FERNANDES, M. A. ENRÍQUEZ \& R de J. C. e ALAMINO (Eds.), Rio de Janeiro: CETEM/MCTI (pp. 333-359).

Sánchez, L. E. (2010). Planejamento e gestão do processo de recuperação de áreas degradadas. In J. M. F. ALBA (Ed.), Recuperação de áreas mineradas (2nd ed., pp. 103-121). Brasília: Embrapa Informações Tecnológicas.

Sarkis, J., Zhu, Q., \& Lai, K. H. (2011). An organizational theoretic review of green supply chain management literature. International Journal of Production Economics, 130(1), 1-15. https://doi.org/10.1016/j.ijpe.2010.11.010

Saunder, D. A., Hobbs, R. J., \& Margules, C. R. (2000). Biological consequences of ecosystem fragmentation: a review. Conservation Biology, 18-32. https://doi.org/10.1111/j.1523-1739.1991.tb00384.x

Scliar, M. (2007) História do Conceito de Saúde. PHYSIS: Rev. Saúde Coletiva, Rio de Janeiro, 17(1), $29-41$. https://doi.org/10.1590/S0103-73312007000100003

Senante, M. M., Marques, R. C., Perez, F., Gomes, T., Garrido, R. S., \& Caballero, R. (2016). Assessing the sustainability of water companies: A synthetic indicator approach. Ecological Indicators, 61. https://doi.org/10.1016/j.scitotenv.2014.08.026

Seroa Da Motta, R. (coord.) (1995). Contabilidade Ambiental: Teoria, Metodologia e Estudos de Casos no Brasil. Rio de Janeiro: IPEA.

Siche, R. (2007). Índices versus indicadores: precisões conceituais da discussão da sustentabilidade de países. Ambiente e Sociedade, X(2), 137-148. https://doi.org/10.1590/S1414-753X2007000200009

Therivel, R. (2010). Strategic Environmental Assessment in action (2nd ed.). London: Earthscan.

Tundisi, J. G., Scheuenstuhl, M. C. B., Campos, D. A., Fernandes, J., Trevisan, P., \& Vieira, V. (2014). Recursos hídricos no Brasil: problemas, desafios e estratégias para o future (p. 76). Academia brasileira de ciências. Rio de Janeiro.

Vasconcelos, S. C. S., Vasconcelos, C. I. S., \& Neto, J. M. M. (2013). Riscos ambientais causados na extração mineral: estudo de caso em uma mineração à céu aberto. Polêmica Revista Eletrônica, 12(2).

Viana, M. B. (2012). Avaliando minas: índice de sustentabilidade mineral (ISM). Tese de doutorado. Centro de 
Desenvolvimento Sustentável. Universidade de Brasília. Brasília.

Yin, R. K. (2009). Case Study Research: Design and Method (3rd ed.). Sage, London, UK.

Younger, P. L. (2006). The water footprint of mining operations in space and time-a new paradigm for sustainability assessments (pp. 13-21). In Proceedings of the Australasian Institution of Mining and Metallurgy Water in Mining Conference. Brisbane, Australia.

Yu, J., Yao, S., Chen, R., Zhu, K., \&Yu, L. (2005). A quantitative integrated evaluation of sustainable development of mineral resources of a mining city: a case study of Huangshi. Eastern China Resources Policy, 30, 7-19. https://doi.org/10.1016/j.resourpol.2004.08.006

\section{Copyrights}

Copyright for this article is retained by the author, with first publication rights granted to the journal.

This is an open-access article distributed under the terms and conditions of the Creative Commons Attribution license (http://creativecommons.org/licenses/by/4.0/). 